\title{
Value Addition of Chapathi with Germinated Pulses and its Popularization
}

\author{
P. Indumathy ${ }^{1 *}$ and J. Pavithra ${ }^{2}$ \\ ${ }^{1}$ Associate Professor and Head of Foods and Nutrition, Vellalar College for Women, Erode - 638012, Tamil Nadu, \\ India; indumathy@vcw.ac.in \\ 2Student, M.Sc. Foods and Nutrition, Vellalar College for Women, Erode - 638012, Tamil Nadu, India
}

\begin{abstract}
A study on "Formulation of germinated pulses incorporated chapathi and its popularization" was conducted as germinated pulses are highly nutritive and contain large amounts of proteins, vitamins and minerals. Bengal gram, green gram and horse gram were selected for the study. The selected pulses were germinated, dried and powdered separately and incorporated in wheat chapathies at 10\%, 20\% and 30\% levels. Organoleptic evaluation was done to assess the acceptability using five point Hedonic scale. Best results were obtained for $10 \%$ incorporation with germinated Bengal gram flour and horse gram flour whereas germinated green gram was well accepted at $30 \%$ level. Germinated pulses incorporated chapathies were found to be rich in protein, calcium, magnesium, iron, zinc, B-complex vitamins, vitamin C and fibre. Incorporation of germinated pulses in chapathi was popularized among 50 home makers of Arappampalayam village in Erode District.
\end{abstract}

Keywords: Germinated Pulses, Popularization, Standardization, Value Addition

\section{Introduction}

India is the world's largest producer and consumer of pulses. Pakistan, Canada, Burma, Australia and the US, in that order are significant exporters and are India's most significant suppliers. Canada now accounts for approximately $35 \%$ of global pulse trade each year. The global pulse market is estimated at 60 million tones]. Pulses provide protein, complex carbohydrate, fibre, low glycemic index, nutrient dense, low in bad cholesterol, vitamins and minerals in the body?

Pulses supply the same amount of calories as cereals i.e., $350 \mathrm{kcal}$ per $100 \mathrm{~g}$ dry weight. The protein content of pulses is about $20 \%$ to $25 \%$ about twice as much as that of cereal making them the most economical source of protein Pulses are part of a healthy balanced diet and have been shown to have an important role in preventing illness such as cancer, diabetes and heart diseasef. The World Health Organization estimates that up to $80 \%$ of heart disease, stroke disease, type- 2 diabetes and cancer could be prevented by eliminating risk factors, such as unhealthy diets and promoting better eating habits of which pulses are an essential component.

The simple measure of soaking pulses in water for two to three days improves their nutritive value and vitamins A \& C content. Germination increased the content of folic acid and other vitamins of B-groups. Tannins and phytates which adversely affect bioavailability are broken down by germination?. Oligosaccharides, such as stachyose and raffinose are reduced in higher amounts during germination than during cooking. Minerals and $\mathrm{B}$-vitamins are retained more effectively during 
germination than with cooking. Phytic acids are reduced significantly but trypsin inhibitor, tannin and saponin reduction is less effective than cooking:

Nutritional composition of pulses includes a high carbohydrate content with slow digestibility of starches, high fibre content, a good source of mono and poly unsaturated fat, plant sterols and micronutrients including selenium, thiamin, niacin, folate, riboflavin, pyroxidine, vitamin-E, A, iron and zin of. Cereals contain $6-12 \%$ protein which is generally deficient in lysine but rich in methionine. The pulses/legumes are of low quality since they are deficient in methionine and red gram is deficient in tryptophan also. However, they are rich in lysine. Cereals when eaten with pulses, as is the common practice in India, the protein quality improves due to mutual supplementation between cereal and pulse proteins, the former being deficient while latter being rich in lysine ?

Germination is a traditional, non-thermal process which improves the nutritional quality of cereals and pulses by increasing nutrient digestibility, reducing the levels or activities of anti nutritional compounds boosting the contents of free amino acids and available carbohydrate and improving functionality/?. Germination has been shown to enhance the bioavailability of minerals such as iron and zinc in cereals and pulses 10 .

Thus the present study was undertaken with the objectives to formulate and standardize and to popularize germinated pulses incorporated chapathi among the public.

\section{Materials and Methods}

\subsection{Selection and Procurement of Ingredients}

The raw materials like Bengal gram, green gram and horse gram were selected for incorporation in chapathi. The main ingredients such as Bengal gram, green gram and horse gram were purchased from local market. The other ingredients such as salt, oil and wheat flour were purchased from local departmental stores.

\subsection{Processing of Ingredients}

Ingredients such as Bengal gram, green gram and horse gram and other ingredients were processed before incorporating in the preparation of chapathi.
Selected pulses were soaked overnight separately. The soaked pulses were allowed to germinate separately. After germination the pulses were dried under sunlight. The dried germinated pulses were roasted on medium flame and were ground using mixie. Processing of germinated pulses powder is shown in the flow chart.

\section{Selection of pulses}

[Bengal gram, green gram and horse gram]

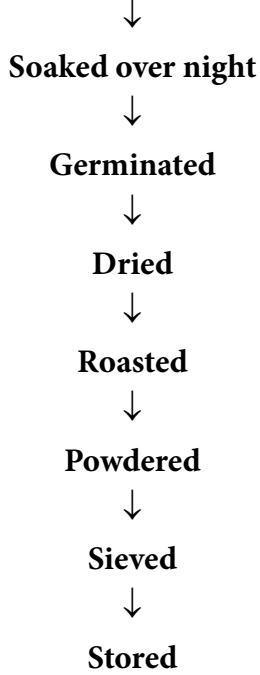

\subsection{Formulation and Standardisation of Germinated Pulses Incorporated Chappathi}

The ingredients such as Bengal gram, green gram and horse gram were roasted and powdered and used for the formulation of value added chapathies. Instead of wheat flour, germinated pulses powder was incorporated at $10 \%, 20 \%$ and $30 \%$ levels by weight of the flour. Another variation of chapathi was prepared using a mixture of germinated Bengal gram, Greengram and Horsegram. The formulation of germinated pulses mix used in the preparation of chapathi is given in Table 1 .

Table 1. Formulation of germinated pulses mix (MGF)

\begin{tabular}{|l|c|}
\hline Ingredients & Amount in grams \\
\hline Germinated Bengal gram Flour & 33.33 \\
\hline Germinated Green gram Flour & 33.33 \\
\hline Germinated Horse Gram Flour & 33.33 \\
\hline
\end{tabular}

The proportion of germinated pulses flour used in the preparation of chapathi is given in Table 2. 
Table 2. Variations and their ingredients

\begin{tabular}{|l|c|c|c|c|c|}
\hline \multirow{2}{*}{ Variations } & \multicolumn{5}{|c|}{ Ingredients in grams } \\
\cline { 2 - 6 } & Wheat flour & GBGF & GGGF & GHGF & MGF \\
\hline STANDARD & 100 & - & - & - & - \\
\hline GBGF V-1 (10\%) & 90 & 10 & - & - & - \\
GBGF V-2 (20\%) & 80 & 20 & - & - & - \\
GBGF V-3 (30\%) & 70 & 30 & - & - & - \\
\hline GGGF V-1 (10\%) & 90 & - & 10 & - & - \\
GGGF V-2 (20\%) & 80 & - & 20 & - & - \\
GGGF V-3 (30\%) & 70 & - & 30 & - & - \\
\hline GHGF V-1 (10\%) & 90 & - & - & 10 & - \\
GHGF V-2 (20\%) & 80 & - & - & 20 & - \\
GHGF V-3 (30\%) & 70 & - & - & 30 & - \\
\hline MGF V-1 (10\%) & 90 & - & - & - & 10 \\
MGF V-2 (20\%) & 80 & - & - & - & 20 \\
MGF V-3 (30\%) & 70 & - & - & - & 30 \\
\hline
\end{tabular}

GBGF - Germinated Bengal gram flour, GGGF - Germinated green gram flour GHGF - Germinated horse gram flour, MGF - Mixed gram flour

\subsection{Sensory Evaluation}

Sensory evaluation is a scientific discipline used to evoke, measure, analyze and interpret reaction to the characteristics of food and materials as they are perceived by the senses of sight, smell, taste, touch and chewing Sensory evaluation was done for the appearance, flavour, taste, texture of germinated pulses flour incorporated chapathi variations. Organoleptic evaluation was done to study the acceptability, using 5 point hedonic rating scale with the help of 50 semi-trained panel members.

\subsection{Cost Calculation}

The cost of germinated pulses incorporated chapathi were calculated for $100 \mathrm{~g}$ of the product and compared with the standard chapathi.

\subsection{General Nutrition Education Highlighting Value Education}

Based on convenience and nativity, Arappampalayam in Erode District was selected for this study. Fifty subjects who were willing to participate and cooperate were selected for popularization of germinated pulses incorporated chapathi. The message on the beneficial effects of germinated pulses was conveyed through lecture and demonstration methods with the help of teaching aids like power point presentation. General nutrition education highlighting value addition, importance of pulses and their usage were explained to the home makers.

\section{Results and Discussion}

\subsection{Organoleptic Evaluation of Formulated Products}

The acceptability of value added chapathies as assessed by organoleptic evaluation are discussed below.

\subsubsection{Acceptability of Germinated Bengal Gram Flour Incorporated Chapathi}

The mean scores for acceptability of standard and germinated Bengal gram flour incorporated chapathi are given in Table 3.

From the table it is evident that next to standard, group $B$ received the highest score for the mean acceptability for all the parameters like appearance, flavor, taste and texture. The mean over all acceptability scores of chapathi decreased with the incorporation of germinated Bengal gram flour. Statistical analysis using ' $t$ ' test did not show any significant difference between the standard and groups B or C. But 30\% germinated Bengal gram incorporated chapathi showed significant difference at $5 \%$ level. 
Table 3. Mean scores for acceptability of germinated Bengal gram flour incorporated chapathi

\begin{tabular}{|l|c|c|c|c|}
\hline \multirow{2}{*}{ Criteria } & \multicolumn{4}{|c|}{ Mean \pm standard deviation } \\
\cline { 2 - 5 } & Group A & Group B & Group C & Group D \\
\hline Appearance & $5.0 \pm 0$ & $5.0 \pm 0$ & $5.0 \pm 0$ & $5.0 \pm 0$ \\
\hline Flavour & $4.95 \pm 0.22$ & $4.95 \pm 0.22$ & $4.85 \pm 0.36$ & $4.8 \pm 0.41$ \\
\hline Taste & $4.9 \pm 0.30$ & $4.7 \pm 0.47$ & $4.75 \pm 0.44$ & $4.35 \pm 0.48$ \\
\hline Texture & $5.0 \pm 0$ & $4.8 \pm 0.52$ & $4.75 \pm 0.44$ & $4.5 \pm 0.51$ \\
\hline Mean over all acceptability & $4.96 \pm 0.13$ & $4.86 \pm 0.30$ & $4.83 \pm 0.31$ & $4.66 \pm 0.35$ \\
\hline Groups compared & & $\mathrm{A}$ and B & $\mathrm{A}$ and C & $\mathrm{A}$ and D \\
\hline 't'value & & $0.859^{\mathrm{NS}}$ & $1.267^{\mathrm{NS}}$ & $2.478^{*}$ \\
\hline Groups compared & & $\mathrm{B}$ and C & $\mathrm{C}$ and D & $\mathrm{B}$ and D \\
\hline 't' value & & $0.180^{\mathrm{NS}}$ & $1.231^{\mathrm{NS}}$ & $1.273^{\mathrm{NS}}$ \\
\hline
\end{tabular}

A - standard chapathi

B - $10 \%$ germinated Bengal gram flour incorporated chapathi

C - $20 \%$ germinated Bengal gram flour incorporated chapathi

D - 30\% germinated Bengal gram flour incorporated chapathi

NS - Not significant

* $-5 \%$ significance

\subsubsection{Acceptability of Germinated Green Gram Flour}

The mean scores for acceptability of standard and germinated green gram flour incorporated chapathi are given in Table 4.

From the table it is evident that next to standard, group $\mathrm{D}$ received the highest score for the mean acceptability for all the parameters like appearance, flavor, taste and texture. The mean acceptability scores of value added chapathi increased with the incorporation of germinated green gram flour.

\subsubsection{Acceptability of Germinated Horse Gram Flour}

The mean scores for acceptability of standard and germinated horse gram flour incorporated chapathi are given in Table 5.

It is evident that next to standard, group $\mathrm{C}$ received the highest score for the mean acceptability for all the parameters like appearance, flavor, taste and texture. But statistical analysis using ' $\mathrm{t}$ ' test did not show any significant difference. Hence it is evident that all the samples matched well with the standard chapathi.

Table 4. Mean scores for acceptability of germinated green gram flour incorporated chapathi

\begin{tabular}{|l|c|c|c|c|}
\hline \multirow{2}{*}{ Criteria } & \multicolumn{4}{|c|}{ Mean \pm standard deviation } \\
\cline { 2 - 5 } & Group A & Group B & Group C & Group D \\
\hline Appearance & $5.0 \pm 0$ & $4.85 \pm 0.36$ & $4.8 \pm 0.52$ & $4.8 \pm 0.61$ \\
\hline Flavour & $4.95 \pm 0.22$ & $4.75 \pm 0.55$ & $4.9 \pm 0.30$ & $4.8 \pm 0.52$ \\
\hline Taste & $4.9 \pm 0.30$ & $4.75 \pm 0.63$ & $4.6 \pm 0.67$ & $5.0 \pm 0$ \\
\hline Texture & $5.0 \pm 0$ & $4.75 \pm 0.78$ & $4.85 \pm 0.48$ & $4.9 \pm 0.30$ \\
\hline Mean over all acceptability & $4.96 \pm 0.13$ & $4.77 \pm 0.58$ & $4.78 \pm 0.49$ & $4.87 \pm 0.35$ \\
\hline Groups compared & & A and B & A and C & A and D \\
\hline 't'value & & $1.973^{*}$ & $1.962^{*}$ & $1.510^{\mathrm{NS}}$ \\
\hline Groups compared & & $\mathrm{B}$ and C & C and D & B and D \\
\hline 't' value & & $0.040^{\mathrm{NS}}$ & $1.377^{\mathrm{NS}}$ & $0.367^{\mathrm{NS}}$ \\
\hline
\end{tabular}

A - standard chapathi

B - $10 \%$ germinated green gram flour incorporated chapathi

C - $20 \%$ germinated green gram flour incorporated chapathi

D - 30\% germinated green gram flour incorporated chapathi

NS - Not significant

* $-5 \%$ significance 
Table 5. Mean scores for acceptability of germinated horse gram flour incorporated chapathi

\begin{tabular}{|l|c|c|c|c|}
\hline \multirow{2}{*}{ Criteria } & \multicolumn{3}{|c|}{ Mean \pm standard deviation } \\
\cline { 2 - 5 } & Group A & Group B & Group C & Group D \\
\hline Appearance & $5.0 \pm 0$ & $4.95 \pm 0.22$ & $4.95 \pm 0.22$ & $4.9 \pm 0.30$ \\
\hline Flavour & $4.95 \pm 0.22$ & $4.9 \pm 0.30$ & $4.95 \pm 0.22$ & $4.8 \pm 0.30$ \\
\hline Taste & $4.9 \pm 0.30$ & $4.85 \pm 0.36$ & $4.9 \pm 0.30$ & $4.8 \pm 0.52$ \\
\hline Texture & $5.0 \pm 0$ & $5.0 \pm 0$ & $5.0 \pm 0$ & $5.0 \pm 0$ \\
\hline Mean over all acceptability & $4.96 \pm 0.13$ & $4.92 \pm 0.22$ & $4.78 \pm 0.49$ & $4.87 \pm 0.35$ \\
\hline Groups compared & & $\mathrm{A}$ and B & $\mathrm{A}$ and C & $\mathrm{A}$ and D \\
\hline 't'value between standard and sample & & $0.547^{\mathrm{NS}}$ & $0.122^{\mathrm{NS}}$ & $1.510^{\mathrm{NS}}$ \\
\hline Groups compared & & $\mathrm{B}$ and C & $\mathrm{C}$ and D & $\mathrm{B}$ and D \\
\hline 't' value between sample & & $0.280^{\mathrm{NS}}$ & $1.291^{\mathrm{NS}}$ & $0.095^{\mathrm{NS}}$ \\
\hline
\end{tabular}

A - standard chapathi

B - $10 \%$ germinated horse gram flour incorporated chapathi

C - $20 \%$ germinated horse gram flour incorporated chapathi

D - 30\% germinated horse gram flour incorporated chapathi

NS - Not significant

\subsubsection{Acceptability of Germinated Mixed Flour}

The mean scores for acceptability of standard and germinated mixed flour incorporated chapathi are given in Table 6.

From Table 6 it is evident that next to standard, group $B$ received the highest score for the mean acceptability for all the parameters like appearance, flavor, taste and texture. The mean overall acceptability scores of the chapathi decreased with the incorporation of germinated mixed flour. ' $\mathrm{t}$ ' value between mean acceptability of standard and group B did not show any significant difference. But $20 \%$ and $30 \%$ germinated mixed flour incorporated chapathi showed significant difference at $5 \%$ level.

On the whole germinated horse gram incorporated chapathi (at 20\% level) received the maximum acceptability scores $(4.95 \pm 0.17)$ by organoleptic evaluation.

\subsection{Cost of Germinated Pulses Incorporated Chapathi}

The cost of $100 \mathrm{~g}$ of standard chapathi flour was Rs. 6.04. The cost of $100 \mathrm{~g}$ of $10 \%, 20 \%$ and $30 \%$ germinated Bengal gram incorporated flour were Rs. 7.58, Rs. 9.12 and Rs. 10.66 respectively. The cost of $100 \mathrm{~g}$ of $10 \%, 20 \%$ and $30 \%$ germinated green gram incorporated flour were Rs. 8.2, Rs. 10.32 and Rs. 12.46 respectively. The

Table 6. Mean scores for acceptability of germinated mixed flour incorporated chappathi

\begin{tabular}{|l|c|c|c|c|}
\hline \multirow{2}{*}{ Criteria } & \multicolumn{4}{|c|}{ Mean \pm standard deviation } \\
\cline { 2 - 5 } & Group A & Group B & Group C & Group D \\
\hline Appearance & $5.0 \pm 0$ & $4 \pm 0$ & $4 \pm 0$ & $4 \pm 0$ \\
\hline Flavour & $4.95 \pm 0.22$ & $4.7 \pm 0.45$ & $4.7 \pm 0.45$ & $4.7 \pm 0.45$ \\
\hline Taste & $4.9 \pm 0.30$ & $4.7 \pm 0.42$ & $4.5 \pm 0.64$ & $4.3 \pm 0.70$ \\
\hline Texture & $5.0 \pm 0$ & $4.4 \pm 0.69$ & $4.3 \pm 0.70$ & $4.3 \pm 0.70$ \\
\hline Mean over all acceptability & $4.96 \pm 0.13$ & $4.7 \pm 0.52$ & $4.6 \pm 0.29$ & $4.5 \pm 0.22$ \\
\hline Groups compared & & $\mathrm{A}$ and B & $\mathrm{A}$ and C & A and D \\
\hline 't'value & & $1.932^{\mathrm{NS}}$ & $2.295^{*}$ & $2.475^{*}$ \\
\hline Groups compared & & $\mathrm{B}$ and C & $\mathrm{C}$ and D & $\mathrm{B}$ and D \\
\hline 't' value & & $0.554^{\mathrm{NS}}$ & $1.05^{\mathrm{NS}}$ & $1.183^{\mathrm{NS}}$ \\
\hline
\end{tabular}

A - standard chapathi

B - $10 \%$ germinated mixed flour incorporated chapathi

C - 20\% germinated mixed flour incorporated chapathi

D - 30\% germinated mixed flour incorporated chapathi

* $-5 \%$ significant 
cost of $100 \mathrm{~g}$ of $10 \%, 20 \%$ and $30 \%$ germinated horse gram incorporated flour were Rs. 8.00, Rs. 9.92 and Rs. 11.86 respectively. The cost of $100 \mathrm{~g}$ of $10 \%, 20 \%$ and $30 \%$ germinated mixed pulses incorporated flour were Rs. 7.93, Rs. 9.78 and Rs. 11.66 respectively.

The cost of the germinated pulses incorporated chapathi flour was high when compared to standard chapathi flour because of the total cost of the pulses. It was found that green gram incorporation was costlier and Bengal gram incorporation was cheaper.

\subsection{Popularisation of Germinated Pulses Incorporated Chapathi}

The public of Arappampalayam were selected to popularize the use of germinated pulses incorporated chapathi. The formulated germinated pulses incorporated chapathi were found to be acceptable through organoleptic acceptability trials. Demonstration and power point presentation methods were used to popularise germinated pulses incorporation inchapathi among the public. They were also encouraged to include the germinated pulses in the daily diet and lead a healthy life.

\section{Conclusion}

Best results were obtained for $10 \%$ incorporation with germinated Bengal gram flour and horse gram flour whereas germinated green gram was well accepted at $30 \%$ level. Value addition of chapathies with germinated pulses improved its protein, calcium, magnesium, iron, zinc, B-complex vitamins, vitamin $\mathrm{C}$ and fibre content. Incorporation of germinated pulses in chapathi was popularized among 50 home makers of Arappampalayam village in Erode District. Nutrition education and popularization of germinated pulses can improve the utilisation of germinated pulses.

\section{References}

1. Chaudhry. Green Gold: Value-added pulses. Quantum media; 2015. ISBN1- 61364696-8.

2. Jatalth VH, Piper JC, Souza RJ, Vanessa, Salma. Nutritional quality of pulses. Journal of Food Nutrition. 2014; 52(2):92-105.

3. Rizkaly SW, Bellisie F, Sathya R, Amirthaveni M, Purushothaman. Health benefits of glycemic index food, Pulses in diabetic patient healthy individuals. British Journal of Nutrition. 2002; 88:255-62. https://doi.org/10.1079/ BJN2002715 PMid:12498625.

4. Curran J. A pulse- based diet is effective for reducing total and LDL-Cholesterol in older adults. British Journal of Nutrition. 2012; 108:51-2.

5. Ibrikci H, Grusak MA, Nicholas, Bampidis VA, Christodoulou. Chick pealeaves as a vegetable green for humans: Evaluation of minerals composition. Journal of the Science of Food and Agriculture. 2003; 83:945-50. https://doi. org/10.1002/jsfa.1427.

6. EI-Adawy TA. Nutritional composition and Antinutritional factors of chick peas undergoing cooking methods and germination. Plant Foods for Human Nutrition. 2002; 57(1):83-97. https://doi.org/10.1023/A:1013189620528.

7. Mudryj AN, Yun, Aukema HM. Nutritional and health benefits of pulses. Appl physiol nutr metab. 2014; 39:1-8. https://doi.org/10.1139/apnm-2013-0557 PMid:25061763.

8. Gopalan C, Ramasastry BV, Balasubramanian SC, Rao BSN, Deosthale YG, Pant KC. Nutritive value of Indian foods. National Institute of Nutrition. Hyderabad: ICMR; 2004.

9. Ribout M, Valverde VC, Baria ZER, Frias J. Food Nutri, 11:39 and Food technol . 2002; 215:472.

10. Gomez M, Oliete B and Rosell CM. Studies on cake quality made of wheat-chickpeas flour blends. LWT-Food Science and Technology. 2008; 41:1701-9. https://doi. org/10.1016/j.lwt.2007.11.024.

11. Meilgaard M, Civille GV, Carr BT. Sensory evaluation techniques. CRC Press; 1999. p. 7-22. https://doi. org/10.1201/9781439832271. 